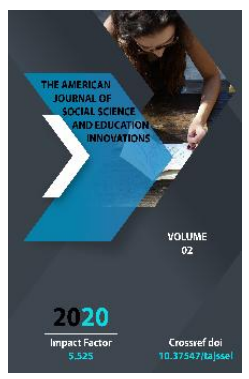

\title{
Views Of Medieval Eastern Scholars On Education And Spiritual Maturity Of The Individual
}

\author{
Kholboev Nuriddin Suyunovich \\ Lecturer Uzbek State Institute of Arts and Culture, Uzbekistan
}

Journal Website:

http://usajournalshub.c

om/index,php/tajssei

Copyright: Original

content from this work

may be used under the

terms of the creative

commons attributes

4.0 licence.

\section{ABSTRACT}

This article provides information on the views of the medieval Eastern scholars Mahmud Kashgari, Abū Nașr Muḥammad ibn Muḥammad al Fārābī , Abu Ali ibn Sina, Ali ibn Abu Bakr, Najm ad-Dīn Kubrà Ahmad ibn Umar ibn Muhammad Khivaqi on education and the spiritual maturity of the individual.

\section{KEYWORDS}

Humanistic ideas, customs, traditions, education, culture, music and human maturity.

\section{INTRODUCTION}

"The world community rightly recognizes that the rich spiritual heritage of our great scientists, writers and thinkers, who grew up in our ancient and unique land on the basis of high humanistic ideas, has made a great contribution to the development of a universal civilization and culture, secular and religious science." [1]

This is a compliment given to the scientific heritage of our great ancestors by the President of the Republic of Uzbekistan Sh.M. Mirziyoyev determines the methodological basis of the scientific booklet presented by us.
It is expedient to say that the contribution and merits of Eastern scientists in the development of world culture and art, world science, education and spiritual development of the individual deserve a high assessment. Taking this brief opportunity, we think of some of our scientists.

This is evidenced by the folk songs created in the VI-VII centuries, which developed in such a way that the organizational forms of everyday life of the Turkic peoples of Central Asia are closely linked with knowledge of speech, customs, traditions, education, culture, music 
and human maturity. Most of the quartets in Maḥmūd al-Kāšğariii’s 11th-century "Dīwān Lughāt al-Turk" are masterpieces of the ancient Turkic people, folk songs, accompanied by music.

\section{MAIN PART}

The work of Abū Nașr Muḥammad ibn Muhammad al Fārābì is of great importance in the history of the development of Eastern culture and the art of music. We all know that Fārābī was known in the East as "Al-Muallim as-Sani" because of his great knowledge in various fields. We find information in many written sources that Fārābī is a great musician. Along with real information about Fārābỉs scientific and creative research, there are also legends. It is narrated that Fārābī knew more than 70 languages. He said, "Whoever wants to learn science, let him start at a young age, be in good health, have good morals and manners, and be able to keep his word, to be protected from evil deeds, to know all the rules, to be knowledgeable and eloquent, to respect the learned and the wise, to have knowledge of all real material things" [2]. We can take as an example the views of medieval scholars on education and the spiritual maturity of the individual. In this way, he paid special attention to the intellectual and moral upbringing of young people as perfect human beings in education, emphasizing that in his belief, knowledge and enlightenment must be adorned with good morals.

Fārābī's contribution to science is enormous. He created about 200 works in various fields philosophy, logic, law, political science, physiology, psychology, educational medicine, mathematics, music, ethics, aesthetics. In his book The Great Book of Music, Fārābī's provides valuable information on the musical endeavors, musical genres and musicians of the time, as well as his research into music.

Abu Ali ibn Sina, who made a great contribution to world science and medicine, also worked in all areas of knowledge of his time. According to some sources, more than 450 of his works have been created. Of these, 242 have been reached so far. His contemporaries, acknowledging Ibn Sina's infinite knowledge and ability, called the great physician "Sheikh ar-rais" (Leader of the Wise). Ibn Sina has five works on music, musicology, music pedagogy:

"Music collection" in "Kitab ash-shifo"; "Summary of music knowledge" section in "Kitab an-najot"; Part of the "Mathematics" section of the "Encyclopedia" and the pamphlet "Introduction to the Art of Music", which has not reached us; In Kitab al-Shifa, the only books known to the author are those who have lost weight.

Ibn Sina was reportedly able to correct patients through music. There are reports that many patients have been told that they can recover by having a knowledge of music, playing any instrument, or learning to sing well.

Ibn Sina expressed his valuable views on child rearing and methods of upbringing. In his views on the moral upbringing of the child, he also speaks about the issues of housekeeping. Raising a child is the main goal and duty of a family parent. A parent who is able to correct their own shortcomings can be an educator.

The most important means of moral education is to advise the child to have a one-on-one conversation without touching his senses and pride. 
Ibn Sina considered the formation of moral qualities in a child in unity with labor, physical and mental upbringing, as a key factor in his development as a human being.

At the beginning of the 12th century in the village of Rishtan of the beautiful city of Margilan in Fergana in 1123, a healthy and talented child was born to the family of Abu Bakr ibn Abdujalil ibn al-Khalil, one of the great lawyers of his time. He was called Ali ibn Abu Bakr. From a young age, Ali ibn Abu Bakr was distinguished by his family members, who won his affection and love. Innate talent, natural ability, sensitive spirit, effort to understand and comprehend were evident in his gait.

Finally, he studied Arabic language and literature at a high level, which is a means of studying all sciences, writing in all fields. His remarkable abilities and abilities in this area can be seen in his works, especially in "Hidoya".

As the relentless efforts of the young scholar in the pursuit of knowledge and the discovery of aspects of his harmonious personality were in the spotlight, the nicknames Shaykh alIslam, Imam Khomeini, and Burhanuddin were added to his full name, Ali ibn Abu Bakr ibn Abdujalil ibn al-Khalil al-Farghani alMarghinani.

Imam Humam means a high-willed and highly respected religious leader, Every word of Burhanuddin in religious affairs and Shari'a science represents a scholar who stands at the level of a document and a burhan, that is, a solid proof.

Ali ibn Abu Bakr, in the course of his tireless efforts and long journeys, went to the schools of knowledge of that century and knocked on the door. At the age of 33, he embarked on a pilgrimage in $544 \mathrm{AH}$ (1150 AD) and had the privilege of visiting the tombs first of the Ka'batullah and then of the Prophet Muhammad (S.A.W.).

During a fruitful trip, the scientist talked with famous scientists from Turkestan to Khorasan, Iran, Iraq and Arabia. According to the Islamic encyclopedia, he wrote down what he read and saw during his lifetime in separate notebooks, as was customary at that time, but, unfortunately, these manuscripts have not reached us.

Najm ad-Dīn Kubrà Ahmad ibn Umar ibn Muhammad Khivaqi, one of the brightest stars of the mystical world of the XII-XIII centuries, was born and raised in Khiva, Khorezm in 540 $\mathrm{AH}(1145 \mathrm{~m}) \cdot$ [3]

Najm ad-Dīn Kubrà went to Tabriz in search of knowledge, where he took lessons from Imam Abu Mansur Hafda. In Tabriz, he also learned many external and internal sciences related to mysticism from such great mystical sages as Sheikh Bobo Faraj Tabrizi, Ammar Yasir and Ismail Kasri. Najm ad-Dīn Kubrà, wearing a hirqa from the hand of Ismail Kasri, returned to his first sheikh, Ruzbekhon al-Misri.

Seeing that Ruzbekhon Najm ad-Dīn Kubrà fully understood the basics of mysticism, he encouraged him to go to his native Khorezm and work to spread the teachings of mysticism. Najm ad-Dīn Kubrà returned to his homeland, with his family, on his orders. After settling there, he established a khanaqah, which is also mentioned in the sources as "atTarika-tuz-zahabiya", meaning "Golden sect". He founded the Kubravian sect and began to interpret the mystical teachings of this sect. 
Soon, many disciples and disciples gathered around the founder of the new sect and set out on this path. Among them, a number of famous Sufis of the XII-XIII centuries grew up and became known as murshids and wali.

According to Ali Akbar Dehkhuda's famous "Lug'atnoma" because of his immense intelligence and inexhaustible intelligence, he was able to solve any problem when asked and win over the one who argued with him, so he was called "at-Tommatul- Kubrà" (great disaster). According to Shamsiddin Sami, the word "at-Tomma" was gradually abandoned in the process of speech, and the word "alKubrà" (great) became an integral part of his nickname, Najm ad-Dīn Kubrà.

\section{CONCLUSION}

Najm ad-Dīn Kubrà's last life in Khorezm was very difficult, intense and difficult. During this period, due to various internal and external factors, the Mongol invasions of Turkestan intensified, and Genghis Khan's army was able to invade the major cities of Transoxiana one by one. In July 1221, one of Genghis Khan's generals, Hulagukhan, surrounded the fortress of Urgench with his young son's army. The city of Urgench was under siege, and Najm ad-Dīn Kubrà, in his seventies, gathered an army from the people and defended the fortress from enemy attacks for several days with weapons in his hands. He was martyred in a fierce battle with his disciples against the Mongol invaders. This event took place in July $618 \mathrm{AH}-1221 \mathrm{AD}$.

In short, if we study the invaluable heritage of hundreds of oriental thinkers and scientists who laid the foundations of world science, making a unique contribution to the development of world science, culture and art, education and spiritual maturity of the individual, we will not be able to conduct research. We believe that this scientific research will continue for many more years.

\section{REFERENCES}

1. About the organization of reading competitions among young people in order to widely study and promote the creative heritage of our great scholars, writers and thinkers. Resolution of the President of the Republic of Uzbekistan N PQ-372

2. Eweblight. com. Thoughts of Eastern thinkers on child rearing.

3. Tokhtaeva D. The role and educational significance of music in the works of Eastern thinkers. BMI.Tashkent:2017.

4. Ganieva I.A. "History of music of the Eastern countries". Tashkent: 2010

5. Wexler S.M; Karomatov F.M. "History of Uzbek music". Tashkent: 1981 